\title{
Morphometric Observations on Three Populations of Schizaphis graminum (Rondani), a Main Wheat Aphid Pest in Brazil
}

\author{
Verônica E. Rubin-de-Celis ${ }^{1}$, Dirceu N. Gassen², Sídia M. Callegari-Jacques ${ }^{3}$, \\ Vera L. S. Valente ${ }^{4,5}$ and Alice K. Oliveira ${ }^{4}$
}

${ }^{1}$ Facultad de Ciencias Biologicas, Laboratorio de Entomologia, Universidad Ricardo Palma. Casilla Postal 18, Lima, Peru.

${ }^{2}$ Centro Nacional de Pesquisa do Trigo, Embrapa, Caixa postal 569, 99001-970, Passo Fundo, RS.

${ }^{3}$ Departamento de Estatística, Instituto de Matemática, Universidade Federal do Rio

Grande do Sul, Av. Bento Gonçalves 9500, 91501-970, Porto Alegre, RS.

${ }^{4}$ Departamento de Genética, Instituto de Biociências, Universidade Federal do

Rio Grande do Sul, Caixa postal 15053, 91501-970, Porto Alegre, RS.

${ }^{5}$ Corresponding author.

An. Soc. Entomol. Brasil 26(3): 417-428 (1997)

Morphometric Observations on Three Populations of

Schizaphis graminum (Rondani), a Main Wheat Aphid Pest in Brazil.

RESUMO - O afídeo verde Schizaphis graminum (Rondani) é uma praga importante em gramíneas. Amostras deste afídeo foram coletadas em três localidades brasileiras caracterizadas por diferentes condições ambientais, Passo Fundo (RS), Jaguariuna (SP) e Dourados (MS).Formas vivíparas aladas e ápteras foram criadas na linhagem de trigo (Triticum aestivum) BR-35 sob condições controladas em laboratório e estudadas e quanto à sua variabilidade em medidas do tamanho do corpo e produção de descendência. Técnicas univariadas (ANOVA) e multivariadas (funções discriminantes canônicas) foram usadas para avaliar diferenças entre as tres populações. Diferenças conspícuas entre populações foram observadas no comprimento de cinco estruturas das formas aladas e oito das ápteras, bem como na produção de descendência. A maior dispersão no comprimento de estruturas dos indivíduos em geral, obtida pela função discriminante canônica foi para a população de Passo Fundo, onde as condições climáticas são mais severas e onde os afídeos causam dano mais sério à cultura de trigo.

PALAVRAS-CHAVE: Insecta, Homoptera, morfometria.

ABSTRACT - The green aphid Schizaphis graminum (Rondani) is an important pest of Graminae. Samples of this aphid were collected at three environmentally distinct Brazilian localities, Passo Fundo (RS), Jaguariuna (SP) and Dourados (MS). Alatae and apterous viviparous forms were reared on the BR35 wheat (Triticum aestivum) strain under controlled laboratory conditions and studied as to their variability in measures of body size and production of progeny. Univariate (ANOVA) and multivariate (canonical discriminant functions) techniques were used to evaluate differences among the three populations. Conspicuous differences between populations were observed in the length of five 
structures of the alatae and eight of the apterous forms, as well as in offspring production. The greatest dispersion in the length of general structures of the individuals obtained by the canonical discriminant function was for Passo Fundo, where climatic conditions are more severe and where aphids cause the most serious damage to wheat crop.

KEY WORDS: Insecta, Homoptera, morphometry.

Among the insect pests responsible for serious damage to various cultivated plants around the world, the aphid Schizaphis graminum (Rondani) is one of the most damaging. This species attacks particularly wheat (Triticum aestivum) fields in Brazil, where their frequency was very high in the 70's, probably due to the absence of natural enemies. The damage caused by aphids seems to be mainly due to their potential of transferring to the plants, viruses such as the barley yellow dwarf milled red leaf (Blackman and Eastop 1985) and the barley yellow dwarf (BYD) which are important diseases of wheat and other grain cereals. These luteoviruses are persistently aphid-transmitted.

The use of body metric characters coupled with other quantitative traits to assess genetic divergence among natural insect populations has been largely accepted by several research groups, especially by those which use Drosophila as an experimental organism (Stalker and Carson 1947, Prevosti 1955, Tantawy and Mallah 1961, David and Bocquet 1975, Giorgi et al. 1990, Brncic 1991, Budnik et al. 1991). Tantawy and Mallah (1961) described the differences in size between the populations of $D$. melanogaster (Meigen) and D. simulans (Sturtevant) in their distribution from north to south. The same authors also observed differences in sexual proportions related to environmental temperatures.

Such interpopulational differences for genetic quantitative traits have clear adaptative significance and could be interpreted as a consequence of microevolutionary processes. If such an approach is applied to aphid populations, the putative interpopulational differences may reflect different genetic attributes, probably related to the efficiency of this pest organism in each type of environment and host exploited (Dixon et al. 1982a, Dixon 1985a).

Studying morphological characteristics such as antenna and leg lengths of other aphid species, Dixon et al. (1982b) observed the influence of temperature and food quality on these variables. By considering these characteristics and others such as life cycles, reproductive biology, resistance to low temperatures and insecticides as well as dispersal parameters, Dixon (1985b) obtained consistent information on the structure of aphid populations.

Despite Dixon's and co-workers studies on several aphids, very little information is available on $S$. graminum. This species is characterized by a high rate of fecundity, due to its parthenogenetic phase which occurs during the summer, when it attacks several other plants. Indeed, this remarkable multiplication capacity is one of the reasons why it is a dangerous pest. In 1970, a systematic Aphid Biological Control Program was established at the Centro Nacional de Pesquisa do Trigo, Empresa Brasileira de Pesquisa Agropecuaria (CNPT-EMBRAPA) as an alternative to the use of pesticides. The results obtained indicated that wheat aphids are a secondary pest in Southern Brazil. However, data from EMBRAPA also suggest that under favorable weather conditions the aphid population increases. Thus, studies on wheat resistance to aphids are of major importance in helping biological agents control pests. The aim of this study is to contribute to the knowledge of the biology of $S$. graminum, so as to 
evaluate the potential of quantitative measures of this aphid for population and adaptative strategies studies which could be used as a tool in biological control programs.

\section{Material and Methods}

Sixty samples of ten apterous and ten allatae forms of S. graminum were taken from experimental wheat fields (1994) in three different Brazilian localities: Passo Fundo (PF) ( $\left.28^{\circ} 15^{\prime} \mathrm{S} ; 52^{\circ} 24^{\prime} \mathrm{W}\right)$, state of Rio Grande do Sul (RS); Jaguariuna (J)(22 $41^{\circ}$ 'S; 46 $59^{\circ}$ 'W ) state of São Paulo (SP); and Dourados (D) (22 ${ }^{\circ} 9^{\prime} \mathrm{S} ; 54^{\circ} 50^{\prime} \mathrm{W}$ ), state of Mato Grosso do Sul (MS).

All samples were maintained in environmental chambers (Phitotron), under $18^{\circ} \mathrm{C}, \mathrm{RH}$ of $65 \%$ and a photoperiod of 12 hours at the Centro Nacional de Pesquisa do Trigo Empresa Brasileira de Pesquisa Agropecuária (CNPT - EMBRAPA) in Passo Fundo. Seeds of BR-35 wheat strain were placed in 50 flower-pots for each populations, when these plants were $3 \mathrm{~cm}$ high they were infested with aphid nymphs. As soon as the wheat plant reached a height of $4 \mathrm{~cm}$, or when the leaves became yellow, the aphids were transferred to a new flower-pot with other $3 \mathrm{~cm}$ wheat plants.

We studied both alatae and apterous adults of the same generation, mounted according to the Hille Ris Lambers(1950) method. Eleven variables (body dimensions, including wing length) and progeny number on the alatae forms and 10 on the apterous forms were measured under the microscope, using an ocular micrometer with 100 divisions, each corresponding to $0.03 \mathrm{~mm}$. The number of offspring was also assessed by visual inspection. Figure 1shows the body dimensions measured in both alatae and apterous forms. They were:antennal segments (SA) II, III, IV, V, VI; body total length(B); siphunculi (S); cauda $(\mathrm{C})$ and proboscis (PAS) .

One-way analysis of variance (ANOVA), and Tukey tests for multiple comparisons of means were used to perform an univariate evaluation of morphological differences be-

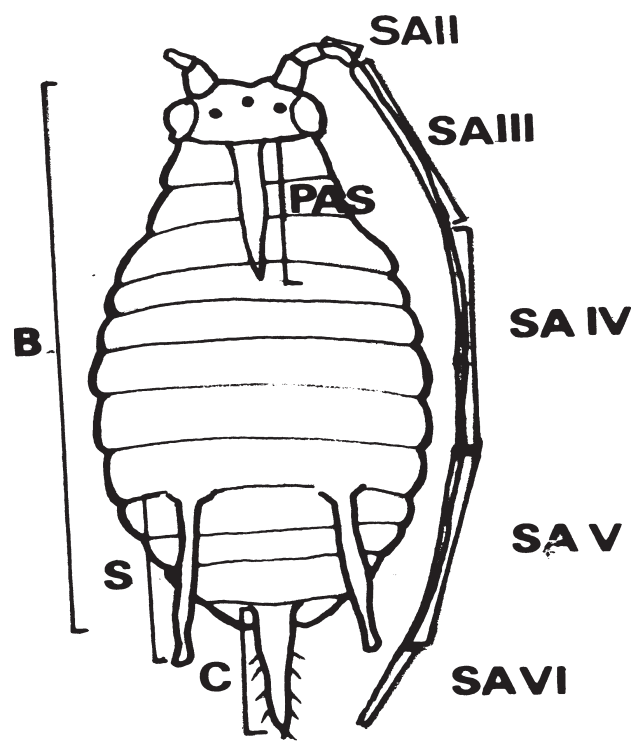

Figure 1. Dimensions measured on the body of alatae(with exception of the wings) and apterous forms of Schizaphis graminum. SAII, III, IV, V, VI and PAS correspond to antennal segment II, antennal segment III, antennal segment IV, antennal segment V, antennal segment VI, and proboscis respectively. B means total body length; S, siphunculi and $\mathrm{C}$, cauda.

tween samples. A multivariate approach followed, by means of a canonical discriminant analysis.

\section{Results}

Univariate Analysis. For the 11 variables observed in the alatae adult forms of $S$. graminum, the means and the corresponding ANOVA and Tukey tests for the three populations studied were estimated (Table 1). Although heterogeneity was found among variances for some variables, the ANOVA is still a robust procedure as long as sample sizes are equal or near equal, as in the present case (Zar 1984). The three populations differed with respect to the total length of the body, length of antennae and of SAIII segments and 
Table 1. Mean $( \pm \mathrm{SD})^{1}$ for variables observed in alatae forms of the Passo Fundo, Dourados and Jaguariuna populations of Schizaphis graminum.

\begin{tabular}{lccccc}
\hline Variables & $\begin{array}{c}\text { Passo Fundo } \\
\mathrm{n}=161\end{array}$ & $\begin{array}{c}\text { Dourados } \\
\mathrm{n}=160\end{array}$ & $\begin{array}{c}\text { Jaguariúna } \\
\mathrm{n}=158\end{array}$ & $\mathrm{~F}$ & $\mathrm{P}$ \\
\hline Body & $1.74 \pm 0.127 \mathrm{~b}$ & $1.88 \pm 0.140 \mathrm{a}$ & $1.60 \pm 0.082 \mathrm{c}$ & 216.57 & $<0.0001^{*}$ \\
Antenna & $1.33 \pm 0.112 \mathrm{a}$ & $1.34 \pm 0.081 \mathrm{a}$ & $1.12 \pm 0.070 \mathrm{~b}$ & 288.77 & $<0.0001^{*}$ \\
SA III & $0.37 \pm 0.089 \mathrm{ab}$ & $0.44 \pm 0.711 \mathrm{a}$ & $0.31 \pm 0.028 \mathrm{~b}$ & 3.92 & $0.020^{*}$ \\
SA IV & $0.21 \pm 0.035$ & $0.41 \pm 1.411$ & $0.24 \pm 0.716$ & 2.27 & 0.104 \\
SAV & $0.19 \pm 0.032$ & $0.29 \pm 1.002$ & $0.16 \pm 0.018$ & 2.37 & 0.094 \\
SAVI & $0.13 \pm 0.052$ & $0.16 \pm 0.713$ & $0.09 \pm 0.018$ & 1.22 & 0.295 \\
PSA VI & - & $0.47 \pm 0.010 \mathrm{a}$ & $0.38 \pm 0.039 \mathrm{~b}$ & 901.24 & $0.000^{*}$ \\
SS III & $17.28 \pm 0.957 \mathrm{a}$ & $17.82 \pm 1.378 \mathrm{~b}$ & - & 16.61 & $0.0001^{*}$ \\
Siphunculi & $0.23 \pm 0.041$ & $0.36 \pm 1.018$ & $0.29 \pm 0.081$ & 1.897 & 0.151 \\
Cauda & $0.15 \pm 0.129$ & $0.19 \pm 0.712$ & $0.13 \pm 0.009$ & 0.774 & 0.462 \\
Offspring & $13.8 \pm 3.01 \mathrm{a}$ & $18.2 \pm 1.15 \mathrm{c}$ & $16.2 \pm 1.02 \mathrm{~b}$ & 203.36 & $<0.0001^{*}$ \\
\hline
\end{tabular}

${ }^{1}$ Means (for each line) indicated by different letters differ significantly at the 0.05 level, using the Tukey test.SA III - Antennal segment III; SA IV - Antennal segment IV; SA V - Antennal segment V; SA VI - Antennal segment VI; PSA VI - Proboscis; SS III - Secondary rhinary.* Significance.

number of offspring. They did not differ with respect to the dimensions of SAIV, SAV, SAVI, siphunculi and cauda. Due to the small length of SAII, the measures were sometimes obtained with low precision. So, we decided to exclude such dimension of the statistical tests. The same was done respect to the wing measures because these structures were frequently broken.

Considering the general differences among the three populations, the Dourados population, has the largest body (average $=1.74 \mathrm{~mm}$ ), whereas the Passo Fundo population shows an intermediate value and the Jaguariuna the lowest $(1.60 \mathrm{~mm})$. Considering offspring number, however, the Passo Fundo population showed the lowest scores (13.8), the Dourados population being the most prolific (18.2) , and Jaguariuna presented an intermediate number (16.2).

In respect to antenna, Dourados population has longer structures followed by Passo Fundo, and than Jaguariuna, but for the antennal segment SAIV, for wich Jaguariuna shows the intermediate value. The dimension
PSAVI could not be measured in the Passo Fundo samples because its appearance was very contracted in the preparations. On the other hand, SSIII was not measured in Jaguariuna because it was too frequently broken.

Significant differences were obtained among the three populations considering all variables except SAVI of apterous forms (Table 2). In contrast with the alatae forms, the apterous aphids from Passo Fundo are the largest individuals (average body length: 2.09 $\mathrm{mm}$ ), Jaguariuna being intermediate $(1.87 \mathrm{~mm})$ and those of Dourados, the smallest $(1.60 \mathrm{~mm})$. The antenna of the apterous forms from Jaguariuna are longer than those of Dourados and Passo Fundo (the shortest). This trend was not observed in the measures of SAIII, SAIV, SAV and PSAVI in which the Dourados population have the smallest score. The largest progeny was observed in the Jaguariuna populations (13.1) whereas Dourados and Passo Fundo populations yield in average respectively 12.2 and 9.1 descendants. 
Table 2. Mean $( \pm \mathrm{SD})^{1}$ for variables observed in apterous forms of the Passo Fundo $\left(28^{\circ} 15^{\prime} \mathrm{S} ; 52^{\circ} 24^{\prime} \mathrm{W}\right)$, Dourados $\left(22^{\circ} 9^{\prime} \mathrm{S} ; 54^{\circ} 50^{\prime} \mathrm{W}\right)$ and Jaguariuna $\left(22^{\circ} 41^{\prime} \mathrm{S} ; 46^{\circ} 59^{\prime} \mathrm{W}\right)$ populations of Schizaphis graminum.

\begin{tabular}{llllrc}
\hline Variables & $\begin{array}{c}\text { Passo Fundo } \\
\mathrm{n}=161\end{array}$ & $\begin{array}{c}\text { Dourados } \\
\mathrm{n}=160\end{array}$ & $\begin{array}{c}\text { Jaguariúna } \\
\mathrm{n}=158\end{array}$ & $\mathrm{~F}$ & $\mathrm{P}$ \\
\hline Body & $2.09+0.213 \mathrm{a}$ & $1.60 \pm 0.144 \mathrm{~b}$ & $1.87 \pm 0.261 \mathrm{c}$ & 216.43 & $<0.0001^{*}$ \\
Antenna & $1.10 \pm 0.764 \mathrm{a}$ & $1.31 \pm 0.290 \mathrm{~b}$ & $1.83 \pm 0.188 \mathrm{c}$ & 96.30 & $<0.0001^{*}$ \\
AS III & $0.43 \pm 0.082 \mathrm{~b}$ & $0.31 \pm 0.148 \mathrm{a}$ & $0.62 \pm 0.724 \mathrm{c}$ & 21.41 & $<0.0001^{*}$ \\
SA IV & $0.41 \pm 0.065 \mathrm{c}$ & $0.25 \pm 0.102 \mathrm{a}$ & $0.36 \pm 0.059 \mathrm{~b}$ & 185.78 & $<0.0001^{*}$ \\
SAV & $0.27 \pm 0.047 \mathrm{ab}$ & $0.22 \pm 0.100 \mathrm{a}$ & $0.34 \pm 0.708 \mathrm{~b}$ & 3.44 & $0.033^{*}$ \\
SAVI & $0.18 \pm 0.115$ & $0.22 \pm 0.727$ & $0.17 \pm 0.713$ & 0.342 & 0.720 \\
PSA VI & $0.64 \pm 0.088 \mathrm{~b}$ & $0.30 \pm 0.210 \mathrm{a}$ & $0.60 \pm 0.123 \mathrm{c}$ & 261.61 & $<0.0001^{*}$ \\
Siphunculi & $0.36 \pm 0.628 \mathrm{a}$ & $0.29 \pm 0.159 \mathrm{a}$ & $0.53 \pm 0.108 \mathrm{~b}$ & 16.17 & $<0.0001^{*}$ \\
Cauda & $0.35 \pm 0.030 \mathrm{a}$ & $0.26 \pm 0.118 \mathrm{~b}$ & $0.34 \pm 0.046 \mathrm{a}$ & 74.01 & $<0.0001^{*}$ \\
Offspring & $9.1 \pm 1.42 \mathrm{a}$ & $12.2 \pm 1.08 \mathrm{~b}$ & $13.1 \pm 2.426 \mathrm{c}$ & 240.45 & $<0.0001^{*}$ \\
\hline
\end{tabular}

${ }^{1}$ Means (within each line) indicated by different letters differ significantly at the 0.05 level, using the Tukey test.SA III - Antennal segment III; SA IV - Antennal segment IV; SA V Antennal segment V; SA VI - Antennal segment VI; PSA VI - Proboscis.* Significance.

Multivariate Analysis. The results obtained in the canonical discriminant functions for the alatae forms of $S$. graminum ( Tables $3,4,5$ ) demonstrate that the two functions were statistically significant and the canonical correlations ( 0.83 and 0.70$)$ indicate good discriminating power. The percentage of correctly classified in individuals was $88 \%$ (Table 5). Correlations among the discriminant variables and the canonical discriminant functions for the alatae forms were performed (Table 4). In function 1, the total length of the antennae and the body indicated correlations higher than 0.6 whereas the number of offspring was the most

Table 3. Canonical discriminant functions obtained for A) the alatae and B) the apterous forms of three populations of Schizaphis graminum from Passo Fundo ( $28^{\circ} 15^{\prime}$ S ; $\left.52^{\circ} 24^{\prime} \mathrm{W}\right)$; Dourados (22 ${ }^{\circ}$ 'S;54 50 ' W) and Jaguariuna (22 $\left.41^{\prime} \mathrm{S} ; 46^{\circ} 59^{\prime} \mathrm{W}\right)$.

\begin{tabular}{lcrrrrrrrr}
\hline Fcn & $\begin{array}{c}\text { Eigen } \\
\text { value }\end{array}$ & $\begin{array}{c}\text { \% of } \\
\text { variance }\end{array}$ & \multicolumn{1}{c}{$\begin{array}{c}\text { Cum Canonical } \\
\text { corr }\end{array}$} & $\begin{array}{c}\text { After } \\
\text { fcn }\end{array}$ & $\begin{array}{c}\text { Wilks' } \\
\text { Lambda }\end{array}$ & $\chi^{2}$ & df & P \\
\hline $\mathbf{A}$ & & & & & & & & & \\
$1^{*}$ & 2.2442 & 69.86 & 69.86 & .8317 & 0 & .156621 & 875.054 & 18 & .0000 \\
$2^{*}$ & .9681 & 30.14 & 100.00 & .7013 & 1 & .508114 & 319.567 & 8 & .0000 \\
& & & & & & & & & \\
$\mathbf{B}$ & & & & & & & & & \\
$1 *$ & 3.2723 & 76.17 & 76.17 & .8752 & 0 & .115675 & 1024.560 & 18 & .0000 \\
$2^{*}$ & 1.0235 & 23.83 & 100.00 & .7112 & 1 & .494200 & 334.787 & 8 & .0000 \\
\hline
\end{tabular}

Model with both: Wilks/ Lambda $=0.157 \quad \chi^{2}=875.05 \quad$ df $=18, \quad \mathrm{P}=000$

Wilks/Lambda $=1.508 \quad \chi^{2}=319.56 \quad \mathrm{df}=8 \quad \mathrm{P}=000$

* Marks correspond to the two discriminant functions remaining in the analysis. 
Table 4 . Pooled within group correlations between discriminants variables and canonical discriminants function for A) alatae and B) apterous forms of Schizaphis graminum .

\begin{tabular}{llcc}
\hline & Structures & Function 1 & Function 2 \\
\hline A & Antenna & $.70944^{*}$ & -.29421 \\
& Body & $.62135^{*}$ & .21200 \\
SAIII & $.08372^{*}$ & .02773 \\
SAV & $.05788^{*}$ & .05039 \\
SAVI & $.04686^{*}$ & .01486 \\
Cauda & $.03401^{*}$ & .02603 \\
Offspring & .15474 & $.90709^{*}$ \\
Sphunculi & .01753 & $.08674^{*}$ \\
SAIV & .04140 & $.07671^{*}$ \\
& & $.52283^{*}$ & .09474 \\
& Body & $.51723^{*}$ & .46034 \\
& BSAVI & $.47232^{*}$ & .21133 \\
& SAIV & $.26867 *$ & .26671 \\
Spunculi & -.43373 & $.61602^{*}$ \\
Offspring & -.11447 & $.59243^{*}$ \\
Antenna & .05538 & $.27845^{*}$ \\
SAIII & .03141 & $.25064^{*}$ \\
Cauda & .02255 & $.11144^{*}$ \\
SAV &
\end{tabular}

* Denotes largest absolute correlation between each variable and any discriminant function. relevant discriminant related to function 2 ( $\mathrm{r}$ ranging from -0.29 to 0.01). $=0.91$ ). All other variables, although present A territorial map (Fig.2) obtained for the in the functions, had less important roles $(r$ three populations on the two functions indi-

Table 5. Classification of individuals of the three groups of A) alatae and B) apterous forms of Schizaphis graminum by means of discriminant functions.

\begin{tabular}{lcccc}
\hline & & \multicolumn{3}{c}{ Predicted group membership } \\
\cline { 3 - 5 } Actual group & No. of cases & 1 & 2 & 3 \\
\hline A & \multirow{2}{*}{161} & 116 & 30 & 15 \\
Group 1 & & $72.0 \%$ & $18.5 \%$ & $9.3 \%$ \\
Passo Fundo & 160 & 3 & 152 & 5 \\
Group 2 & & $1.9 \%$ & $95.0 \%$ & $3.1 \%$ \\
Dourados & 158 & 4 & 1 & 153 \\
Group 3 & & $2.5 \%$ & $0.6 \%$ & $96.8 \%$ \\
Jaguariuna & \multirow{2}{*}{161} & 149 & & \\
B & & $92.5 \%$ & $0.6 \%$ & $6.8 \%$ \\
Group 1 & & 2 & 136 & 23 \\
Passo Fundo & 161 & $1.2 \%$ & $84.5 \%$ & $14.23 \%$ \\
Group 2 & & 19 & 7 & 134 \\
Dourados & 160 & $11.9 \%$ & $4.4 \%$ & $83.3 \%$ \\
Group 3 & & & & \\
Jaguariuna & & & & \\
\hline
\end{tabular}

Percent of "grouped" cases correctly classified: $87.89 \%$ 


\section{Canonical Discriminant Functions}

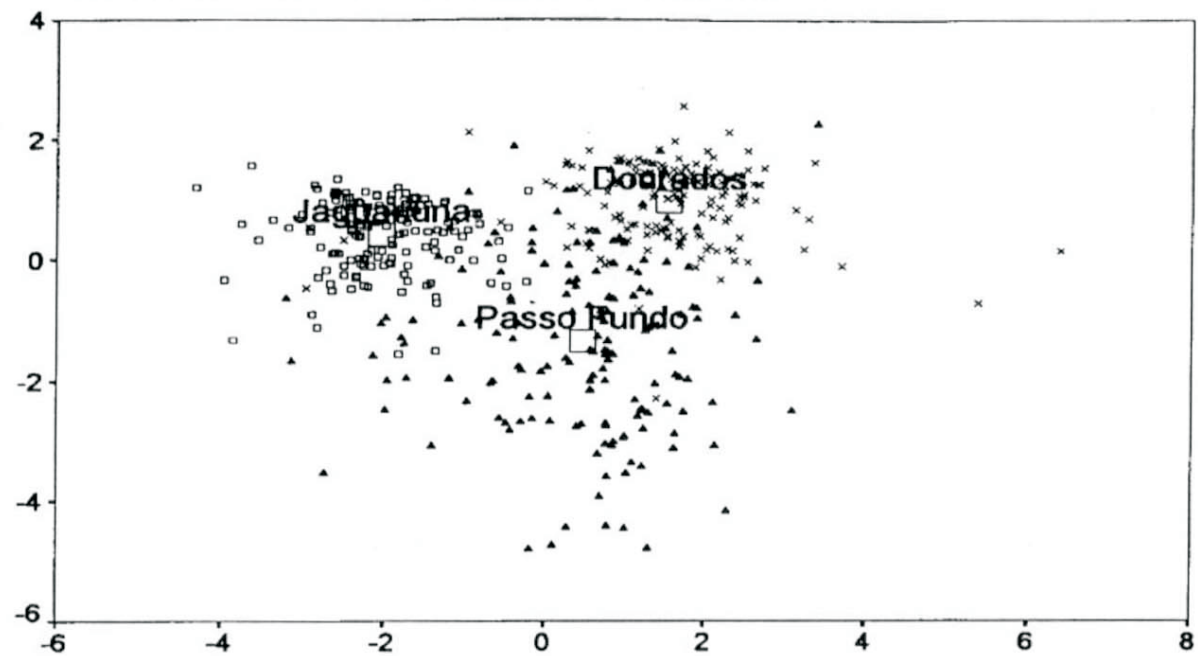

\section{Function 1}

Figure 2. Territorial map drawn according to the canonical discriminant functions of alatae forms of Schizaphis graminum from three different populations: Passo Fundo $\bullet\left(28^{\circ} 41^{\prime} \mathrm{S} ; 52^{\circ}\right.$ $\left.24^{\prime} \mathrm{W}\right)$, Jaguariuna • (22 41'S; $\left.46^{\circ} 59^{\prime} \mathrm{W}\right)$ and Dourados $\mathbf{x}\left(22^{\circ} 9^{\prime} \mathrm{S} ; 54^{\circ} 50^{\prime} \mathrm{W}\right)$. Group centroids are indicated by a square.

cate that function 1 discriminates between Jaguariuna and Dourados, whereas function 2 scores separates the Dourados from the Passo Fundo population.

The values of two discriminant scores for the alatae forms relative to the Passo Fundo population present a higher dispersion than those observed for Jaguariuna and Dourados (Fig.3).

The results of the canonical discriminant analysis for the apterous form of $S$. graminum (Table 3), as observed for the alatae forms, the canonical correlations were high $(0.88$ and 0.71 ), and $87 \%$ of the cases were correctly classified.

The correlations between discriminant functions and discriminant variables showed a somewhat different pattern in the apterous forms (Table 5). Four variables (total length of the body, PSAVI, SAIV and number of offspring) presented absolute correlation coeffi- cients higher than 0.4 when correlated with function 1 scores, but two of them (PSAVI and number of offspring) had high coefficients also for the second function. The total length of antennae had also a moderately high value $(r=0.59)$ for function 2 .

When we analyzed the territorial map drawn for the two discriminant functions relative to the apterous forms of $S$. graminum (Fig. 4), it was observed that function 1 discriminates between the Dourados and Passo Fundo populations whereas the function 2 scores separate Jaguariuna from the other two populations. The analysis of the scores of the two canonical discriminant functions of apterous forms of the $S$. graminum populatinos (Fig. 5) revealed that, similar to what was observed in the alatae forms (Fig. 3), Passo Fundo populations presented a broad distribution of values, but in this case Jaguariuna has a greater dispersion than Dourados. 


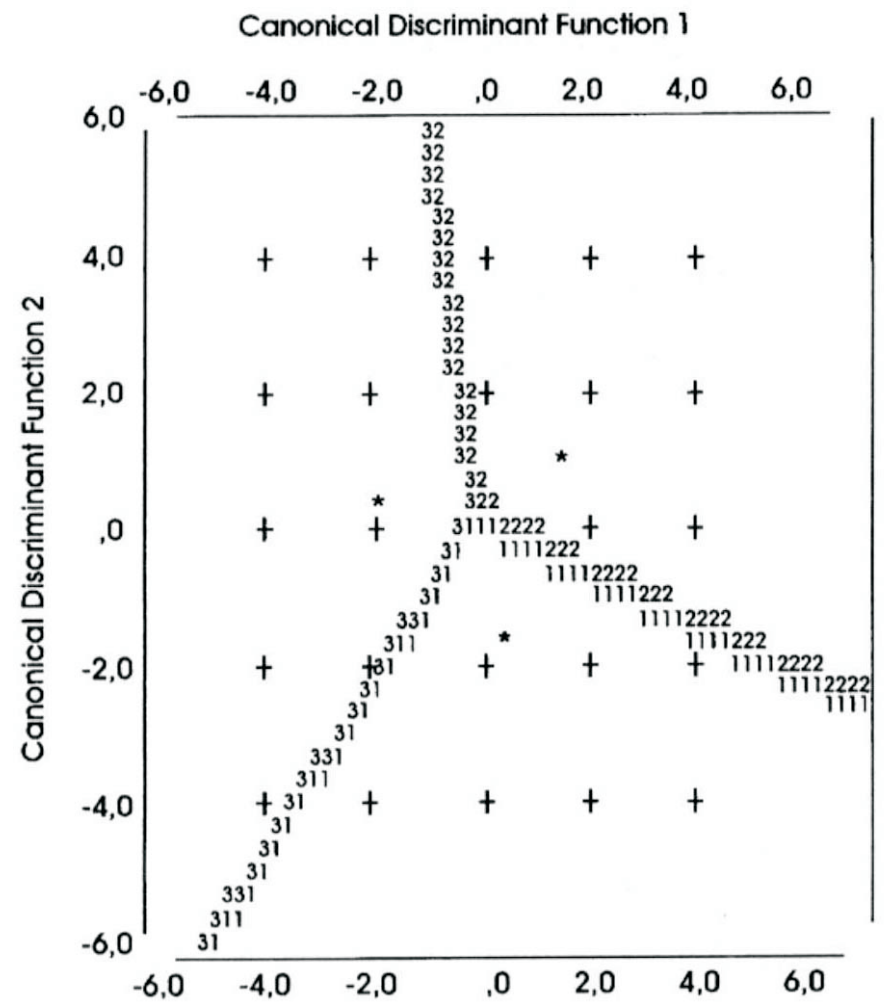

Figure 3. Plotting of the scores of the two discriminant functions obtained for the alatae forms of Schizaphis graminum from three different populations.1) Passo Fundo ( $28^{\circ} 15^{\prime} \mathrm{S} ; 52^{\circ}$ $\left.24^{\prime} \mathrm{W}\right), 3$ ) Jaguariuna (22 $\left.{ }^{\circ} 41^{\prime} \mathrm{S} ; 4^{\circ}{ }^{\circ} 59^{\prime} \mathrm{W}\right)$ and 2) Dourados (22 $\left.{ }^{\circ} 9^{\prime} \mathrm{S} ; 54^{\circ} 50^{\prime} \mathrm{W}\right)$.

\section{Discussion}

Environmental conditions such as food quality and availability, besides climatic factors, are capable of influencing the variation in quantitative characteristics of aphid populations, such as body length dimensions and offspring production numbers (Dixon et al. 1982b, Dixon 1985a,b). Although the three aphid populations studied came from distant places, all the individuals were reared in the same host wheat plant, the BR-35 strain, thus eliminating the different nutritional effects. Furthermore, the effect of temperature and RH oscillations common in Brazil, were also discarded, because our samples were maintained under rigorously controlled conditions in spe- cial chambers, where such variables were constant and especially suited to aphid rearing . Thus, we can "a priori" consider that the variability observed in our samples was due to genetic determination.

Evidence from the univariate analysis suggest that not all dimensions measured were useful for distinguishing among the three populations. The total body length was significantly different among the three populations. But some structures appear to contribute more effectively to body length variations, such as SAIII, PSAVI and SSIII for the alatae forms and SAIII, SAIV, SAV and PSAVI for the apterous forms.

These analyses were considerably improved by the use of the multivariate ap- 


\section{Canonical Discriminant Functions}

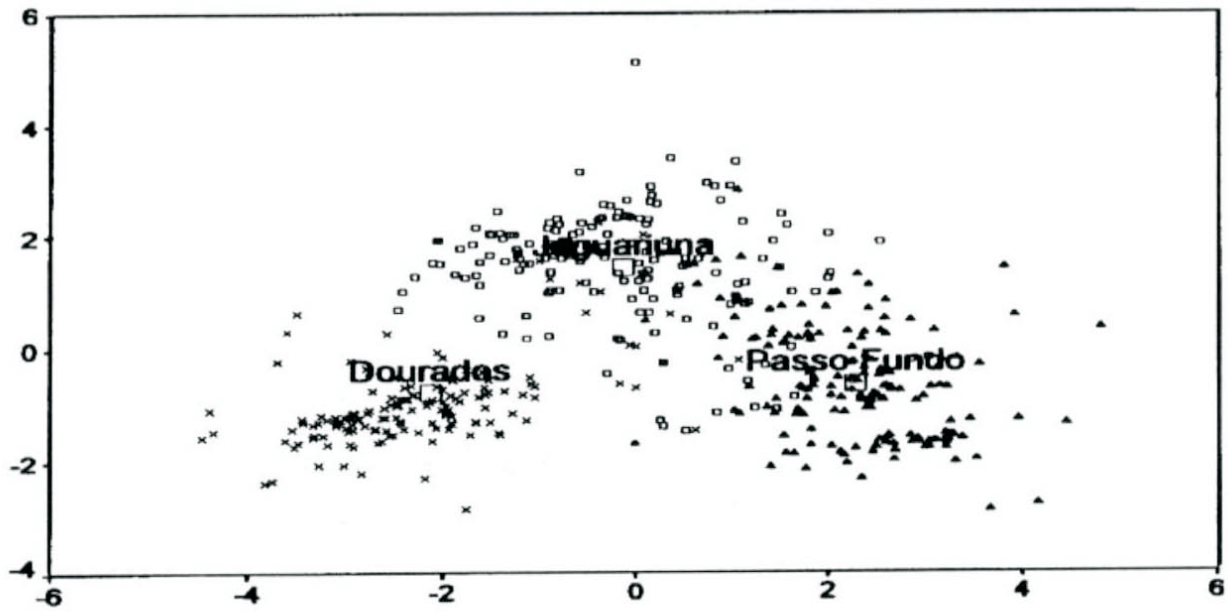

\section{Function 1}

Figure 4. Territorial map drawn according to the canonical discriminant functions of apterous forms of the Schizaphis graminum from three different populations: Passo Fundo $\left(28^{\circ}\right.$ $\left.15^{\prime} \mathrm{S} ; 52^{\circ} 24^{\prime} \mathrm{W}\right)$, Jaguariuna $\bullet\left(22^{\circ} 41^{\prime} \mathrm{S} ; 46^{\circ} 59^{\prime} \mathrm{W}\right)$ and Dourados $\mathbf{x}\left(22^{\circ} 9^{\prime} \mathrm{S} ; 54^{\circ} 50^{\prime} \mathrm{W}\right)$. Group centroids are indicated by a square.

proach. The 87.89 and 86.93 percentages of individuals correctly classified, respectively, for alatae and apterous forms ensures that the populations can be differentiated using canonical discriminant funtions.

In fact, by comparing the results of both univariate and multivariate analyses, it seems clear that total body length is a quite informative dimension, together with number of offspring, to characterize different aphid populations. The antenna dimensions as a whole or parts of this structure (PSAVI and SAIV) are also informative to distinguish populations, both for the apterous and alatae forms. Thus, it is suggested that these variables could be used preferentially in future quantitative aphids populations studies.

These findings are relevant, if we consider that these parameter scores are essential to fitness, since it supports the establishment of the aphid populations in spite of their natural enemies and environmental conditions.
Thus, some generalizations can be made. The values of the alatae forms of Passo Fundo populations tend to be more widely dispersed than those of the remaining populations (Fig. 4). In the Passo Fundo region climatic conditions are more extreme, ranging from about $0^{\circ} \mathrm{C}$ in winter to roughly $35^{\circ} \mathrm{C}$ in summer. The other populations (Jaguariuna and Dourados) are subject to less marked temperature variations (minimum values in both places are considerably higher). However, although the Passo Fundo alatae forms of $S$. graminum present more genetic variability than the other two, their number of offspring is smaller, suggesting a particular adaptive strategy of this population.

As mentioned by Dixon $(1976,1985 b)$, Dixon et al.(1980), and Leather et al. (1983) the reproductive and flight strategies of the alatae forms of each aphid species can be related to the quality of the habitat exploited. Burns (1971) reinforces the idea that flight is 


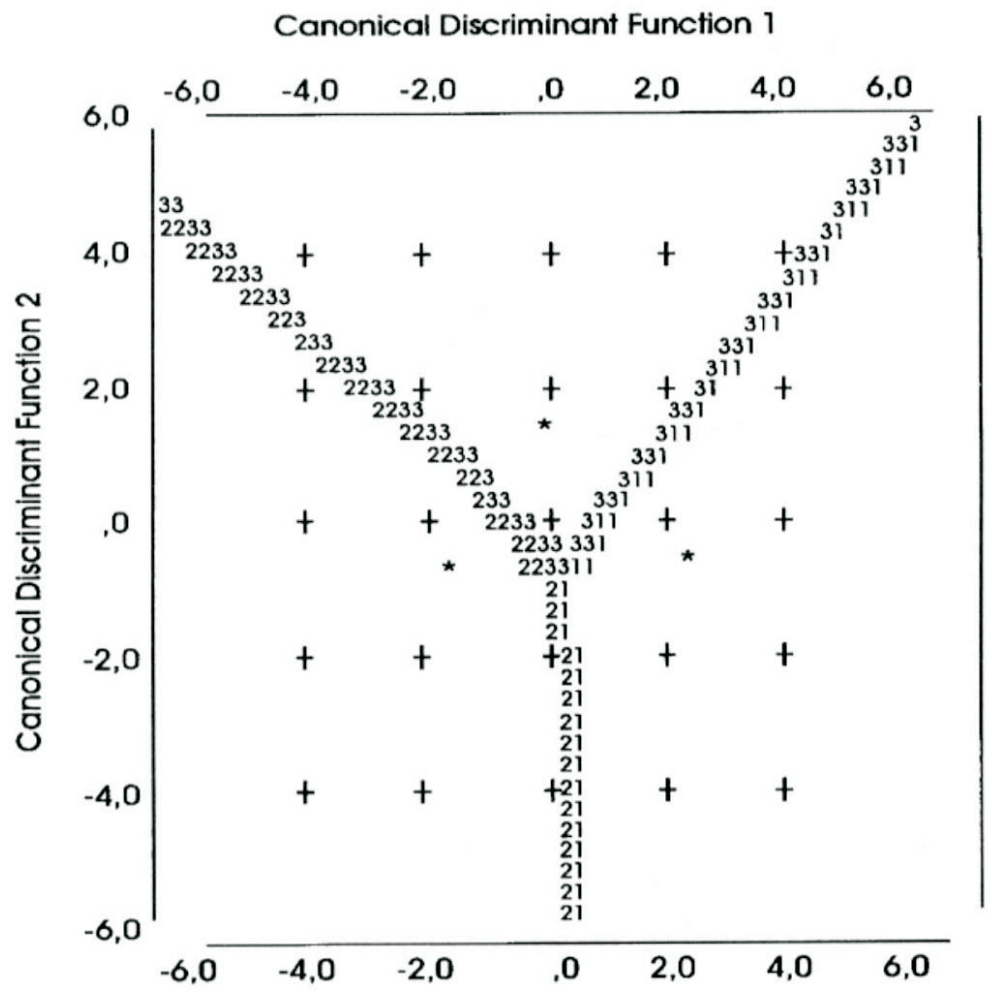

Figure 5. Plotting of the scores of the two canonical discriminant functions obtained for the apterous forms of Schizaphis graminum from three different populations: 1) Passo Fundo $\left(28^{\circ} 15^{\prime} \mathrm{S} ; 52^{\circ} 24^{\prime} \mathrm{W}\right)$; 3) Jaguariuna (22 $\left.41^{\prime} \mathrm{S} ; 46^{\circ} 59^{\prime} \mathrm{W}\right)$ and 2 ) Dourados (22 $\left.9^{\prime} \mathrm{S} ; 54^{\circ} 50^{\prime} \mathrm{W}\right)$.

costly in terms of fecundity and reproductive rates. Thus, the Passo Fundo populations seems to be able to face more variable environmental conditions than the Jaguariuna and Dourados alatae forms, but at the expense of diminished progeny.

When the distribution of the values of apterous forms was considered, we observed that the dispersion of values was not so broad in the Passo Fundo population, resembling that which occurs with the values of Jaguariuna populations. The Dourados population, once again presents the least variable scores for the dimensions studied.

These value distribution patterns, seem to reflect different selective forces imposed by the climate conditions of the original environment of the populations. The Dourados cli- mate is characterized as hot and humid throughout most of the year, whereas the Jaguariuna climate has intermediate characteristics between Dourados and Passo Fundo.

Differently from what is suggested by Dixon $(1976,1977)$ and Dixon and Mercer (1983), both the alatae and apterous forms of the three populations of $S$. graminum, seem to explore the same reproductive strategy, the number of offspring of Dourados and Jaguariuna being similar and higher than those of the Passo Fundo population. Dixon $(1985 a, b)$ states that climate is perhaps the main factor responsible for the differences in genotypes among aphid populations, followed by the adaptation to an heteroecious life cycle. This appears to be true for the $S$. graminum populations studied here. 
Considering our findings from the agricultural standpoint, we can suggest looking for more intensive biological control programs in the Passo Fundo populations, where the greatest genetic variability of the $S$. graminum was revealed.

\section{Acknowledgements}

Thanks are due to Conselho Nacional de Desenvolvimento Científico e Tecnológico (CNPq), Fundação de Amparo à Pesquisa do Estado do Rio Grande do Sul (FAPERGS), Pró-Reitoria de Pesquisa e Pós-Graduação da Universidade Federal do Rio Grande do Sul (PROPESP-UFRGS), and Financiadora de Estudos e Projetos (FINEP) for financial support.

\section{References Cited}

Blackman, R.L. \& V. F. Eastop. 1985. Aphid on the world's crops: an identification guide. NewYork, John Wiley, 466p.

Brncic, D. 1991. Geographical and seasonal variations in wing size in Chilean populations of Drosophila immigrans. Evol. Biologica 5: 115-122.

Budnik, M. , L. Cifuentes \& D. Brncic. 1991. Quantitative analysis of genetic differentiation among European and Chilean strains of Drosophila subobscura. Heredity 67: 29-33.

Burns, M. 1971. Flight in the vetch aphid, Megoura viciae Buckton. PhD. thesis. Univ. Glasgow, Scotland, 100 p.

David, J. R. \& C. Bocquet. 1975. Evolution in a cosmopolitan species: genetic latitudinal clines in Drosophila melanogaster wild populations. Experientia 31: 164-166.

Dixon A.F.G. 1976. Reproductive strategies of the alate morphs of the bird cherry-oat aphid Rhopalosiphum padi L. J. Anim. Ecol. 45: 817-830.

Dixon A.F.G. 1977. Aphid ecology: life cycles, polymorphism and population regulation. Annu. Rev. Ecol. Syst. 9: 117 -118 .

Dixon, A.F.G. 1985a. Structure of aphid populations. Annu. Rev. Entomol. 30: 155-174.

Dixon, A.F.G. 1985b. Aphid ecology. Glasgow, Blackie, 157 p.

Dixon, A.F.G. \& T.R. Dharma. 1980. Spreading of the risk in developmental mortality: size, fecundity and reproductive rate in the black bean aphid. Entomol. Exp. Appl. 28: 301-312.

Dixon, A.F.G. \& P. W. Wellings. 1982a. Seasonality and reproduction in aphids. Int. J. Invertebr. Reprod. 5: 83-89.

Dixon, A.F.G., R. J. Chambers \& T. R. Dharma. 1982b. Factors affecting size in aphids with particular reference to the black bean aphid, Aphis fabae. Entomol. Exp. Appl. 32: 123-128.

Dixon, A.F.G. \& D. R. Mercer. 1983. Flight behaviour in the sycamore aphid: Factors affecting take-off. Entomol. Exp. Appl. 33: 43-49.

Giorgi, G., V. Natali, D. Guerra \& C. Pezzoli. 1990. Inter and intraspecific genetic divergence between Italian populations of two Drosophila sibling species. Evol. Biologica 4: 1-21.

Hille Ris Lambers, D. 1950. On mounting aphids and other soft skinned insects. Ent. Berichten. Amst. 13: 55-58.

Leather, S.R., S. A. Ward \& A. F. G. Dixon. 1983. The effect of nutrient stress on some life history parameters of the black 
bean aphid Aphis fabae Scop. Oceanología 57: 156-157.

Prevosti, A. 1955. Geographic variability in quantitative traits in populations of Drosophila subobscura. Cold Spring Harbor Symp. Quant. Biol. 20: 294-299.

Stalker, H.D. \& H. L. Carson. 1947. Morphological variation in natural populations of Drosophila robusta Sturtevant. Evolution 1: 237-248.
Studies on natural populations of Drosophila. I. Heat resistance and geographical variation in Drosophila melanogaster and Drosophila simulans. Evolution 15: 1-14.

Zar, J. 1984. Biostatistical analysis. Englewood Cliffs, N. J. 2nd edition. Prentice-Hall, Inc. 718 p .

Tantawy, A.O. \& G. S. Mallah. 1961. Received 29/VIII/96. Accepted 19/VIII/97. 